\title{
QUEEN'S
UNIVERSITY
BELFAST
}

\section{From manifestos to praxis: developing criticality in healthcare simulation}

McNaughton, N., \& Gormley, G. (2021). From manifestos to praxis: developing criticality in healthcare simulation. BMJ Simulation and Technology Enhanced Learning, 7(3), 123-125. https://doi.org/10.1136/ bmjstel2020-000821

Published in:

BMJ Simulation and Technology Enhanced Learning

Document Version:

Publisher's PDF, also known as Version of record

Queen's University Belfast - Research Portal:

Link to publication record in Queen's University Belfast Research Portal

Publisher rights

(c) 2021 The Authors.

This is an open access article distributed

in accordance with the Creative Commons Attribution

Non Commercial (CC BY-NC 4.0) license, which permits

others to distribute, remix, adapt, build upon this work

non-commercially, and license their derivative works on

different terms, provided the original work is properly

cited, appropriate credit is given, any changes made

indicated, and the use is non-commercial. See: http:/l

creativecommons.org/licenses/by-nc/4.0/.

General rights

Copyright for the publications made accessible via the Queen's University Belfast Research Portal is retained by the author(s) and / or other copyright owners and it is a condition of accessing these publications that users recognise and abide by the legal requirements associated with these rights.

Take down policy

The Research Portal is Queen's institutional repository that provides access to Queen's research output. Every effort has been made to ensure that content in the Research Portal does not infringe any person's rights, or applicable UK laws. If you discover content in the

Research Portal that you believe breaches copyright or violates any law, please contact openaccess@qub.ac.uk. 


\section{From manifestos to praxis: developing criticality in healthcare simulation}

\author{
Nancy McNaughton (10 1,2 Gerard Gormley (1) 3,4
}

\section{INTRODUCTION}

The authors of 'a manifesto for healthcare simulation practice' have crafted a call to action for the healthcare simulation community in response to the COVID-19 pandemic. ${ }^{1}$ They rightly point to the unprecedented disruption and chaos that this crisis has wrought in our personal lives, our societies and most acutely in healthcare. With great tempo, health professional's have had to develop new ways of providing care for our populations. Similarly, health professions educators have had to be responsive and adaptive in preparing our healthcare workforce and students-with little of the development lead-in time on which they have come to rely.

Within the manifesto, simulationists are being called to incorporate 'a more comprehensive understanding of healthcare simulation beyond tool, technique or experience and instead recognise it as a professional practice' with attendant responsibilities and accountabilities. ${ }^{1}$ These responsibilities include 'adopting a commitment to comprehensive safety, to advocate collaboratively and lead ethically." These noble words reflect the passion and urgency felt by the authors in the face of the disruption and destruction rendered by the pandemic within our field of healthcare simulation. As evidenced by the prolific numbers of COVID-19-related articles, research projects and presentations online - the simulation community across the globe is rising to this new and unique challenge.

Manifestos look to the future. More than promise, they make public their pledge to drive change for new lines of

\footnotetext{
${ }^{1}$ Centre for Learning, Innovation and Simulation, Michener Institute for Applied Health Sciences, Toronto, Ontario, Canada

${ }^{2}$ Institute for Health Policy Management and Evaluation, University of Toronto, Toronto, Ontario, Canada

${ }^{3}$ Centre for Medical Education, Queen's University Belfast School of Medicine Dentistry and Biomedical Sciences, Ireland, UK

${ }^{4}$ Clinical Skills Education Centre, Queen's University Belfast, Belfast, UK

Correspondence to Dr Nancy McNaughton, Centre for Learning, Innovation and Simulation, Michener Institute for Applied Health Sciences, Toronto, ON M5T 1V4, Canada; nmcnaughton565@gmail.com
}

action in our global simulation community. While looking forward, we argue that we must also look inward into our simulation community and critically ask ourselves questions about our community, values and relationships within the wider arena of health professions education.

\section{THE ROLE OF CRITICAL THEORY MOVING INTO THE FUTURE}

By drawing on concepts and ideas, theories help us to understand the world around us. Critical theories are one such group of theories that support us in challenging norms and taken for granted practices in the interests of social justice and those most burdened in our societies.

From this perspective, simulation-based education (SBE) inspires an important form of knowledge production especially for the benefit of those in need of healthcare. It is a methodology through which we learn and create new knowledge and ideas about competence and what this looks like in training and practice. By virtue of our location within health professional education contexts, standardised patients or more broadly simulated participants, (SPs) and simulationists negotiate a number of complex power relations. For example, as proxies for the 'real thing', SPs are often 'used' as tools by clinician educators, ${ }^{2}$ effectively reproducing prevailing professional ideas about appropriate physician/patient interactions. 'Used' is a small word, easily missed, perhaps perceived as incidental. However, this choice of words locates SPs within a medical hierarchy as objects and part of the educational apparatus. ${ }^{2}$ Discussions within the field of SBE about the use of the term, standardised patient to globally represent the work of SPs is ongoing. We acknowledge the authors of the manifesto have held to standardised patient as their preferred term. as outlined in the Society for Simulation in Healthcare dictionary. ${ }^{4}$ With the linguistic turn we now know that language does not simply describe but actually constructs the social world and the different ways we may participate and interact. ${ }^{5}$ The importance of this is evident within our community in the continued conversations about what 'SP' refers to and the ways in which the different understandings shape 'the different ways we may participate and interact. ${ }^{5}$ How are we as simulationists unwittingly contributing to the reproduction of the status quo or taken for granted practices within our field?

SBE is a cultural, social', and political undertaking that is embedded in systems of power. In order to prevent reproducing stigmatising stereotypes, and in order to make our taken for granted assumptions visible, we need to embrace the health professions as a social undertaking as well as a clinical one; and to see that pedagogical experiences can powerfully influence professional values and attitudes in clinical practice. Developing criticality and reflexivity can enable praxis in our actions. Praxis according to Paolo Freire is 'reflection and action directed at the structures to be transformed. ${ }^{96}$ It is more crucial than ever in these times to make visible through ethical practices the health and social effects that unaddressed power relations create.

Critical theory perspectives help us understand how prevalent ideas about SPs become embedded in our learning processes, which in turn shape our understanding about relational care that occur in healthcare practitioner and patient interactions. Critical theory also can help reify such concepts into our practice and actions. We encourage the authors and readers of the manifesto to consider the value of critical theory perspectives in shaping the future role of SBE as undeniably changed by COVID-19. As the authors of the manifesto allude to, this will require a shift in our thinking so that the simulation ecosystem continues to evolve in a progressive and responsive manner to the changing world around us; from pandemics to equity in access to healthcare; from advances in healthcare treatments to new diseases.

Modern healthcare is complex, challenging and at times unpredictable. Therefore, it is important that we equip health professionals with skills to navigate and tolerate such complexities. We must not lose sight of complicated real-world realities in our simulations. As opposed to the naturalistic evolving realties of clinical practice, in simulation our realities are constructed by our own ideas and actions in order to create manufactured learning opportunities. In so doing, we must continually narrow the gap between these constructed realities of simulation and the messiness of the clinical environments in which we work. ${ }^{7}$ It behoves us to not over simplify our simulations thereby 
suggesting to our learners that real-world practice is linear and predictable. We need to embrace complexity in our simulations and be grounded in the dynamic challenges of real world clinical practice, or risk falsely reassuring our learners that they are prepared for the often harsh realties of their chosen profession.

\section{THE ETHICAL PRACTICE OF SIMULATION}

The three themes that organise the manifesto: safety, advocacy/collaboration and ethical leadership are connected by an overarching principle of ethics as a hands-on practice. As the authors of the manifesto suggest, healthcare simulation is a professional practice, but more than this, it needs to be advanced as an ethical practice. Education is always an ethical undertaking and as such requires conversations about potential effects on learners and teachers, and on SPs. For SP methodology this is for all parties engaged in a simulation activity, from design to implementation and following into the debriefing process. Ethics as an embodied practice, 'includes(ing) the acknowledgement of and compassion for pain as well as the activity of working through it. ${ }^{8}$ SP-based education, because it involves living people, requires that we think ethically about what we are asking SPs, learners and for that matter teaching faculty to engage in. This framing echoes the ideas put forward in this manifesto as it speaks to the volitional nature of ethics and the connection between our ideas, feelings, decisions and actions and attendant accountability to larger social concerns stemming from this process. As the authors point out, 'essential' in labour perspectives is something quite different from 'essential' as a value in principle. ${ }^{1}$ We would like to take this argument one step further.

SBE is experiential and involves our emotions, minds and our bodies explicitly in the activity of learning and as such asks for a degree of vulnerability that other pedagogical approaches may not. As such, attendant physical and psychological risks to identity and unintended emotional effects need to be considered when planning, designing, implementing and debriefing SP-based activities. This is especially important during these fraught times. Safety is a set of actions that result from the integrity of relationships. The decisions we make about face to face projects and access to SPs as a dynamic source of learning have in principle and in fact potentially life altering consequences. Safety is based on trust. No one can make a person feel safe. Safety is the result of ethical and compassionate principles applied in practice. What processes do we need to put in place to ensure all learners and faculty and simulationists experience trust as a foundation of their learning and work? The authors state

... we believe that there is no justification in subjecting simulationists to additional risk of exposure during simulation activities in any environment that is not under the direct control of the simulationists to the same degree as the simulation center. It should be noted, however, that even incenter work is still at elevated risk compared to working remotely. ${ }^{1}$

How do we turn this ethical intent into action? What does this look like in SBE practice? Ethical principles related to safety will inevitably be in tension with practical and material considerations concerning loss of employment and income. This is an area open for discussion within the community and has no simple answer.

Collaboration is at the heart of simulation as a professional field and practice. And as the authors propose, accepting the norm of accommodation is no longer good enough. We applaud the authors for stating so clearly the tensions that impede the safety and full appreciation for SPs and Simulationists in healthcare.

Too often, simulationists are disempowered and under-resourced, and expected to accommodate to make clinical education work-causing overwork, straining operations, and compromising the wellbeing of simulationists.... Therefore, we must shift our practice from one that tolerates inequitable distribution of power and resources to one that thrives on collaborative mutual respect. ${ }^{1}$

How we think about SP contributions within health professions education is changing. SPs are no longer simply models for others to 'use'. Through their participation as coteachers, and educational allies, they have also helped to develop a methodology that informs the larger field of simulation as well as health professions education more broadly. ${ }^{3}$

SPs are now being valued for their ability to contribute more formally to scenario development, especially those in which emotional presentation and intensity are of central consideration-for example, training in challenging conversations or mental health scenarios. Their involvement potentially ensures that learners are given access to appropriate challenges, which simulation as a methodology so effectively provides.
There are multiple shifts occurring within SBE that are informing the changing roles of SPs. These are occurring in online formats just as they were in face to face environments.

- SPs are assisting in establishing coherence between learning objectives and learning outcomes through their involvement in scenario development.

- SPs contribute to design of simulation scenarios through their attention to aspects of physical, emotional and historical accuracy.

- SPs provide feedback through responsiveness in an interaction as well as during debriefing following an exchange, providing learners with experiences that may endure far after the interaction is finished.

All this work is essentially collaborative. Recognition that SPs are integral players providing educational input from a unique location and as part of an overarching learning plan means that the educational alliance can be turned into opportunities for rich learning. For example, with a greater demand for remote and online simulations (eg, remote video consulting with SPs and learners) we need to ensure that SPs are adequately trained regarding online role-play, provided with sufficient connectivity and accessibility. Often SPs can role-play emotionally charged scenarios such as individuals with suicidality. Therefore, it is important that they adequately de-role and are provided debriefing. After switching off a video link, following an emotionally charged discussion, can be a lonely place even for health professionals and not least for SPs.

\section{CONCLUSION}

With this manifesto the authors are inviting us to take time to reflect, reimagine and realign our simulation endeavours. Given the unique location of SP-based education, within and across health professions education, we have an opportunity to contribute to larger social justice issues such as disparities in access to healthcare, and human rights that this pandemic has made visible. Through praxis-oriented processes simulationists can make visible the impact of power relations on the health and social effects of inequity and lack of inclusion. Possibly, inclusive educational design processes; scenarios that recognise the diversity of people's access to healthcare and their experiences of stigma and judgement inside healthcare settings are a first step.

As espoused by the author Norman Vincent Peale 'Change your thoughts and 
you can change your world ${ }^{9}$ by changing our thinking in simulation related practice we have a chance to change it for the good of all.

The intent of the manifesto to encourage us to do the right thing in the face of emerging tensions and difficulties will be for naught if the words do not lead to action that is informed by our knowledge of inequities and social injustices that the pandemic has laid bare. There is an imperative to train the next generation of health and social care professionals. If we do not do this effectively-then this will have an impact on our societies. We add to the authors call within this manifesto another call-for greater theoretically informed approaches to simulation practice and research. We cannot lose site of the human dimension of what we do as educators in SP-based education. The COVID-19 pandemic has had health, especially mental health, economic and social impact for years to come.

Twitter Nancy McNaughton @uto_nancy and Gerard Gormley @DrGerryG

Contributors Both authors made substantial contributions to the conception and writing of the manuscript. The drafting and revision of the manuscript were carried out by both authors with both contributing intellectual content. Both authors agreed on the final version of the manuscript to be published and are accountable to all aspects of work's integrity.

Funding The authors have not declared a specific grant for this research from any funding agency in the public, commercial or not-for-profit sectors.

Competing interests None declared.

Patient consent for publication Not required.

Provenance and peer review Not commissioned; externally peer reviewed.

\section{(a) \\ OPEN ACCESS}

Open access This is an open access article distributed in accordance with the Creative Commons Attribution Non Commercial (CC BY-NC 4.0) license, which permits others to distribute, remix, adapt, build upon this work non-commercially, and license their derivative works on different terms, provided the original work is properly cited, appropriate credit is given, any changes made indicated, and the use is non-commercial. See: http:// creativecommons.org/licenses/by-nc/4.0/.

(c) Author(s) (or their employer(s)) 2021. Re-use permitted under CC BY-NC. No commercial re-use. See rights and permissions. Published by BMJ.

\section{A Check for updates}

To cite McNaughton N, Gormley G. BMJ Simul Technol Enhanc Learn Epub ahead of print: [please include Day Month Year]. doi:10.1136/ bmjstel-2020-000821
Received 1 November 2020

Accepted 30 December 2020

BMJ Simul Technol Enhanc Learn 2021:0:1-3. doi:10.1136/bmjstel-2020-000821

ORCID iDs

Nancy McNaughton http://orcid.org/0000-0001-95575509

Gerard Gormley http://orcid.org/0000-0002-1701-7920

\section{REFERENCES}

1 Park CS, Clark L, Gephardt G. Manifesto for healthcare simulation practice. BMJ Simul Technol Enhanc Learn 2020;0:1-4.

2 McNaughton N, Anderson M. It's all in the Words, Editorial. Clin Simul Nursing 2017;13:293-4.

3 McNaughton N. The role of emotion in the work of standardized patients: a critical theoretical analysis. Berlin LAP Press, 2012. ISBN: 978-3-659-26257-9.

4 Society for Simulation in Healthcare Dictionary. Available: https://www.ssih.org/Dictionary

5 McNaughton N, Martimianakis MA. Critical Theory. In: Nestel D, Reedy G, McKenna L, et al, eds. Clinical education for the health professions. Singapore: Springer, 2020.

6 Friere P. Pedagogy of the Oppressed. New York: Bloomsbury, 1970.

7 Johnston JL, Kearney GP. Gormley GJ, et al. Into the uncanny Valley: simulation versus simulacrum? Med Educ 2020:54:903-7.

8 Braidotti R. Transpositions: on nomadic ethics. Cambridge, UK: Polity, 2006.

9 Peale N. The power of positive thinking. Englewood Cliffs, N.J: Prentice-Hall, 1956. 